\title{
EFFICIENCY OF DETECTING RESTING SPORES OF SYNCHYTRIUM ENDOBIOTICUM (POTATO WART DISEASE) IN INFESTED SITES OF UKRAINE AND GEORGIA
}

\author{
A. H. Zelya ${ }^{1 *}$, L. A. Janse ${ }^{3}$, J. D. Janse ${ }^{3}$, S. E. Ghoghoberidze ${ }^{2}$, \\ G. V. Zelya ${ }^{1}$, R. O. Kordulean ${ }^{1}$, Z. V. Sikharulidze ${ }^{2}$ \\ ${ }^{1}$ Ukrainian Scientific Research Plant Quarantine Station Institute of Plant Protection NAAS, 1, Naukova Str., \\ Boyany village, Novoselytsky District, Chernivtsi Region, Ukraine \\ ${ }^{2}$ Institute of Phytopathology and Biodiversity of the Batumi Shota Rustaveli State University, \\ 90, Tavisupleba Str., Kobuleti, Georgia, 6200 \\ ${ }^{3}$ Institute of Plant Protection NAAS,33, Vasylkivska Str., Kyiv, Ukraine, 03022
}

E-mail:avrelia.zelya@gmail.com*; liliya.janse@gmail.com; j.janse6@gmail.com;sof.gogoberidze@gmail.com; georgetrexnauk@gmail.com; kordulyanroman@gmail.com; zsikharulidze@ymail.com

Received May 31, 2021 / Received June 22, 2021 / Accepted July 19, 2021

\begin{abstract}
Aim. To determine the occurrence and persistence of Synchytrium endobioticum, resting spore contamination in a small survey of (known infested) potato plots in Ukraine and Georgia; to compare the detection efficiency for resting spores (winter sporangia) of $S$. endobioticum using an extraction method, routinely applied in Ukraine, based on the use of sodium iodide (NaI) and an extraction method largely based on EPPO Standard PM 7/28(2) (2017), using kaolin and calcium chloride $\left(\mathrm{CaCl}_{2}\right)$ for extraction. Methods. The examination of fields, aimed at detecting of $S$. endobioticum in 22 infested plots in Georgia, was conducted following the standard European Plant Protection Organisation (EPPO) phytosanitary procedure PM 3/59(3) (2017), and in Ukraine in 11 plots according to the Ukrainian Standard 'Methodological recommendations on sampling during quarantine inspection and evaluation' (Omeluta V P et al, 1996). Resting spores were extracted using kaolin and $\mathrm{CaCl}_{2}$ (following largely EPPO Standard PM 7/28(2) 2017), and floatation in a solution of NaI (Zelya et al, 2005), respectively. The content of soil organic matter (SOM), collected in potato wart infested plots in Ukraine and Georgia, was determined according to the "Method of laboratory determination of the content of organic matter', largely following the method of Tyurin to determine total soil organic carbon (Jankauskas B et al, 2006). The persistence or decline of potato wart in infested plots was evaluated, based on our own observations and the data of the national phytosanitary services (https://dpss.gov.ua; http://agr.georgia.gov). The results of the study were subjected to statistical analysis, using Statistica 5 software. Results. It was found that under a low up to high level of organic matter in soil samples (2.0-2.7 and 3.1-3.9\%, respectively) and a moderate to high level of inoculum in soil (3-15 up to 41-65 resting spores/g soil, respectively) there were no significant differences in the efficiency of two extraction methods under consideration: the floatation in a solution of $\mathrm{NaI}$ and the application of kaolin and $\mathrm{CaCl}_{2}$. However, at a low number of resting spores present in soil (1-2 resting spores/g soil), the efficiency of the method using NaI decreased statistically significant by $20-30 \%$ as opposed to the method using kaolin/ $\mathrm{CaCl}_{2}$. A relatively high level of soil contamination with resting spores was found in 11 investigated plots of 4 Ukrainian regions: 41-46 resting spores/g soil in the Ivano-Frankivsk Region, 49 in the Lviv Region, 40-65 in the Zakarpattia and 52-65 Chernivtsi Regions. The majority of the 22 investigated Georgian plots showed a low inoculum level (1-7 resting spores/g soil) and only in one village their level amounted to 15 resting spores/g soil (Uchguli village, Mestia municipality). Conclusions. The method applying sodium iodide was found to be comparable to the method applying kaolin and $\mathrm{CaCl}_{2}$ under conditions of moderate to high inoculum levels (15-65 resting spores/g soil) but the latter method was more efficient under conditions of high content of organic matter and very low inoculum level ( $<5$ resting spores/g soil). It is
\end{abstract}

(c) A. H. ZELYA, L. A. JANSE, J. D. JANSE, S. E. GHOGHOBERIDZE, G. V. ZELYA, R. O. KORDULEAN, Z. V. SIKHARULIDZE, 2021 
therefore advisable to implement the EPPO standard method that uses kaolin and $\mathrm{CaCl}_{2}$ in the regional and national testing laboratories in both countries. In Ukrainian potato wart infested plots, the inoculum level of resting spores was found to be 4-20 times higher than in the soil samples originating from the Georgian infested plots, which may have been caused by the difference in climatic and other geographic conditions and/or differences in soil types and agricultural practice. On a national scale in the past 9 years (2011-2020) there has been a decrease by $72.2 \%$ in the area infested by potato wart in Ukraine and by $9.8 \%$ in the level of inoculum in these areas.

Key words: potato wart, winter sporangia, detection, floatation, soil types, organic matter.

DOI: https://doi.org/10.15407/agrisp8.02.036

\section{INTRODUCTION}

The gross yield of the potato production in Ukraine, which is the fourth biggest in the world (20.9 million tons in 2020, the State Statistics Service of Ukraine, http://www.ukrstat.gov.ua/) and a considerable planted area (1.3 million ha, the State Statistics Service of Ukraine, http://www.ukrstat.gov.ua/) demonstrate the relevance of this crop for the agrarian production and the economy of the country. Georgia has a potato production of some 194.700 tons on 16.300 ha (FAOSTAT, retrieved on 27-09-2021) and is in principle self-sufficient (93\%, data 2020, http://www.geostat.ge).

Potato as a crop is a host for many pathogens, including the intracellular obligate pathogen Synchytrium endobioticum Schlibersky Percival, causing potato wart (Baayen R P et al, 2006). Potato wart causes substantial economic losses worldwide. Losses include also loss of the target (export) market due to quarantine status of the causal pathogen, long-term quarantine restrictions (including prohibition of potato growing for 10 to 20 years depending on test results of the infested plots) not only in the infested areas but also in so-called buffer zones, surrounding the infested areas (Przetakiewicz J 2015a, EPPO phytosanitary procedure PM 3/59(3) 2017).

The nature and degree of harmfulness of the disease depend on natural climatic conditions of the growing area, the agro-machinery used, the resistance of the potato variety, soil type and fertility, level of seed farming, rotation scheme, the system of prophylactic and protective measures and other factors (Melnyk PO, 2003; Fiers M et al, 2012; EFSA, 2018). For instance, there was a decrease down to $80-90 \%$ of productivity and quality of potatoes in Ukraine, in (especially) the mountainous regions, where aggressive pathotypes of the disease agent have been and are still widespread (Melnyk PO, 2003; Zelya AG et al, 2017, 2020a). As of 2020 , the total distribution area of $S$. endobioticum in the country is $2,307.2$ ha $(0.17 \%$ of the total cultivated area) (https://dpss.gov.ua/).
Potato wart is included in the list of quarantine diseases in 53 countries worldwide (EPPO Global Database, GB, 2021). At present, there have been 39 pathotypes of $S$. endobioticum described (Przetakiewicz J, 2015b; Przetakiewicz J, 2017; van de Vossenberg B et al, 2018).

In Ukraine, potato wart was first detected in 1938, at a household farm in Slavuta town, Khmelnytsk Region, and in the following two years the infestation reached a total of 407 ha (Melnyk PO, 2003). In the following years, the area of infested soils expanded further. The largest area of potato wart infestation and aggressive pathotypes are found in the mountainous Carpathian region of Ukraine. Factors that play a role in aggravation of the disease situation and development of new pathotypes in this area over the years are: 1) favorable natural climatic conditions of this region; 2) current practice of cultivating potatoes in monoculture and/or without proper rotation scheme; 3 ) long-term cultivation (in combination) of potato varieties with different (low) resistance to potato wart (Zelya A et al, 2017; Zelya A et al, 2018). Similar causes and tendencies were observed in Poland (Przetakiewicz J, 2017), Turkey (Çakir E, Demirci F, 2017) and Sweden (Boberg J, Björklund N, 2018).

To date, five pathotypes have been found to circulate in Ukraine: a conventional (Dahlem) pathotype of potato wart 1(D1), widespread in Chernivtsi Region and 4 aggressive pathotypes: 11(M1) - Mizhhirskyi, 13(R2) Rakhivskyi, 18(Ya) - Yasinivskyi, common for Zakarpattia Region, and 22(B1) - Bystretskyi, common for Ivano-Frankivsk Region. Among these, the most aggressive pathotype was found to be 18(Ya) - Yasinivskyi pathotype (Zelya A H et al, 2017).

From 2011 to 2019 , only $30.8 \%$ potato varieties, resistant to $18(\mathrm{Ya})$ - Yasinivskyi pathotype, were selected out of the total new assortment of potatoes, obtained from different scientific and breeding institutions of Ukraine and tested for resistance to potato wart. Some $52.2 \%$ of the varieties were found resistant to $11(\mathrm{M} 1)-$ 
Mizhhirskyi pathotype, $46.5 \%$ - to 13(R2) Rakhivskyi pathotype, and $71.1 \%$ - to 22(B1) Bystretskyi pathotype. Therefore, potato varieties with complex resistance to the disease agent are recommended for cultivation to control potato wart agent in infested areas with aggressive pathotypes (Zelya A H et al, 2020b). Some 85 out of 191 potato varieties from the State register of plant species of Ukrainian origin (https://sops. gov.ua/reestr-sortiv-roslin), are resistant to the conventional pathotype 1(D1). Only 9 of these potato varieties are resistant to all pathotypes, viz. cvs Bazys, Hlazurna, Kniazha, Misteria, Rodynna, Santarka, Solokha, Sontsedar and Khortytsia. Thus, these are the varieties to be used for planting in all the infested areas in the country (Zelya A H et al, 2018).

$S$. endobioticum was reported from Georgia for the first time in 2014, but was already observed since 2009, possibly 2006 (Gorgiladze L et al, 2014; Sikharulidze ZV, 2019) By 2019 the potato wart spread to two municipalities (23 villages) and is listed as an A2 pest by the Ministry of Agriculture of Georgia (Ghoghoberidze $\mathrm{S}$ et al, 2019). The isolates of S. endobioticum obtained from the villages of Skvana, Uchkho, and Dzirkvadzeebi, Khulo municipality (Georgia) belonged to pathotype 38 (Nevşehir), widespread in Turkey (Ghoghoberidze $\mathrm{S}$ et al, 2020). The level of inoculum (resting spores or winter sporangia) in infested soils in Georgia was not studied in detail till now.

Survey and monitoring studies, aimed at demarcation of infested areas and defining the level of inoculum in the soil considerably depend on the suitability, specificity, sensitivity, and reproducibility of the chosen methods. At present, in Ukraine the most frequently applied detection method for over 23 years has been the method of extraction using solutions of $\mathrm{NaI}$ (Zelya AG et al, 2005). Georgia introduced the European method with EPPO Standard PM 7/28(2) 2017, according to which the extraction of resting spores of $S$. endobioticum from soil samples is done using a kaolin and $\mathrm{CaCl}_{2}$. The aims of our study were: 1) to determine the occurrence and persistence of Synchytrium endobioticum resting spore contamination in a small survey of (known infested) potato plots in Ukraine and Georgia 2) to compare the detection efficiency for resting spores (winter sporangia) of $S$. endobioticum using an extraction method, routinely applied in Ukraine, based on the use of sodium iodide (NaI) and an extraction method largely based on EPPO Standard PM 7/28(2) 2017, using kaolin and calcium chloride $(\mathrm{Cl} 2)$ for extraction.

\section{MATERIALS AND METHODS}

In Georgia 22 infested plots, found infested in a survey in 2020 were sampled according to the EPPO phytosanitary procedure PM 3/59(3), 2017. From each $0.1 \mathrm{ha}$, one mixed sample of $20 \mathrm{~kg}$, consisting of 60 subsamples, taken via a zig-zag pattern, was obtained. In the laboratory two subsamples, $100 \mathrm{~g}$ each from each of the $20 \mathrm{~kg}$ mixed samples, were taken, of which one was used for analysis for each of the two methods to be tested. The geolocation of the samples was determined using GPS navigator eTrex Vista HCx (Garmin (Europe) Ltd.).

Soil samples in the 11 Ukrainian infested plots were collected according to the 'Methodological recommendations on sampling in the process of quarantine inspection and evaluation" (Omeluta V P et al, 1996) from plots, where potato varieties, susceptible to potato wart (cvs Poliska rozheva, Lorkh, Teteriv), were cultivated. Soil samples of $750 \mathrm{~g}$ per plot (5 subsamples) were collected in ' $\mathrm{X}$ ' pattern sampling. The geolocation of the samples was determined using GPS navigator eTrex Vista HCx (Garmin (Europe) Ltd.)

In both countries, soil samples were collected from infested plots, located in mountainous regions c. $500 \mathrm{~m}$ above the sea level, which are characterized by regular sharp fluctuations in day- and night-time temperatures and a mean air humidity over $70 \%$. A total of 11 Ukrainian and 22 Georgian plots were sampled.

To extract resting spores, largely following the EPPO Standard PM 7/28 (2) c. 3.3. (2017), Georgian soil samples were air dried at room temperature and sieved via washing with tap water through sieves of $75 \mu \mathrm{m}$ and $25 \mu \mathrm{m}$. The weighed soil $(100 \mathrm{~g})$ was mixed in a laboratory vortex mixer for $10 \mathrm{~s}$ in $20 \%$ solution of kaolin $\left(\mathrm{Al}_{2} \mathrm{O}_{3} 2 \mathrm{SiO}_{2} 2 \mathrm{H}_{2} \mathrm{O}\right)$ to precipitate organic matter, then centrifuged at 3,000 rpm for $5 \mathrm{~min}$ at the centrifuge LC-425 (BVG, Hungary) at room temperature. The supernatant was discarded and the precipitate obtained centrifuged in a $40 \%$ solution of $\mathrm{CaCl}_{2}$ with the specific weight of 1.4 at 3,000 rpm for $5 \mathrm{~min}$ to extract the resting spores. The supernatant was filtered and resting spores present were counted under a light microscope Bio Light 300 (DELTA optical, Poland) (120x) and their viability was visually assessed. Viable resting spores were grainy and had a triple wall structure with greyish granular content. Non-viable resting spores were not grainy, (partly) plasmolyzed or empty, their wall was often not intact.

To extract resting spores according to the Ukrainian method (Zelya et al, 2005), soil samples were air 
dried at room temperature and sieved through sieves of $0.75 ; 0.50 ; 0.25$, and $0.03 \mathrm{~mm}$. The remaining soil fraction from the last sieve was placed into a $35 \%$ solution of $\mathrm{NaI}$ with the specific weight of 1.2 and centrifuged for $3 \mathrm{~min}$ at the centrifuge LC-425 (BVG, Hungary) at 3,000 rpm. Light admixtures floated on the surface. The supernatant with admixtures was poured out, the precipitate was again suspended in a solution of $\mathrm{NaI}$ with a s.w. of 1.4 and centrifuged again under the same conditions. Resting spores and other small organic material floated on the surface. Spores were counted under a light microscope Bio Light 300 (DELTA optical, Poland) (120x) and their viability was visually assessed.

The content of total soil organic matter (SOM) in the studied soil samples from Ukraine and Georgia, was determined according to the method of Tyurin, based on oxidizing organic matter with a $0.4 \mathrm{~N}$ solution of potassium bichromate in concentrated sulphuric acid till the formation of the carbon dioxide, then the excess of potassium bichromate was isolated by titration, using a solution of ferrous ammonium sulfate (ammonium iron $^{2+}$ sulfate hexahydrate), and the content of organic carbon was determined using an alteration factor of 1.724 to convert the obtained values for total soil organic carbon (SOC), to total soil organic matter (SOM (Jankauskas B et al, 2006).

Statistics of Tables 1 and 2 show means and their standard deviations $(x \pm S E)$. The reliability of differences between samplings was assessed by the dispersion analysis with further evaluation of the least significant difference (LSD) using the Statistica 5 software package.

\section{RESULTS}

Our studies detected the spreading of S. endobioticum, in Berehomet town in Vyzhnytsia District, two villages in the Putyla District, Chernivtsi Region, where the disease had previously been registered (Zelya A H et al, 2012), and also a new plot, in Storozhynets town, where potato wart was detected on the area of 0.2 ha in 2019 (Zelya et al, 2020a).Using the two extraction methods with $\mathrm{NaI}$ and kaolin/ $\mathrm{CaCl}_{2}$, we determined a high level of inoculum in these plots, which amounted to 51-65 resting spores/g soil (Table 1).

In the inspected plots of the Zakarpattia Region, the level of inoculum in soil was detected within the range of 40-65 resting spores/ $\mathrm{g}$ of soil. The differences between the two methods are statistically and practically totally insignificant. In the selected plots of the IvanoFrankivsk Region both methods detected 41-46 rest- ing spores/g soil. Soil samples, collected from Turka town, Lviv Region, contained 49 resting spores/g soil, detected by both methods.

Thus, under a relatively low level of SOM (2.0 $-2.7 \%$, Table 1) and a relatively high level of inoculum in soil (41-65 resting spores/g soil) there were no significant differences in the efficiency of the two extraction methods.

Resting spores of $S$. endobioticum were extracted, using the same two methods as for Ukrainian samples, from 22 soil samples, collected during inspections, from 22 Georgian infested plots. In all the Georgian samples a smaller total amount of resting spores was detected as compared to those from Ukrainian plots: from 1 to 15 resting spores/g soil (Table 2) as opposed to $41-65$ resting spores/g soil in the 11 Ukrainian samples.

As the content of organic matter in soil samples from Georgia was somewhat higher than that in Ukrainian samples (3.1-3.9\% against 2.0-2.7\% respectively, Tables 1 and 2), for the calculation of method efficiency the kaolin $/ \mathrm{CaCl}_{2}$ as standard was taken (as opposed to the calculation in Table 1, where it was vice versa).

The plot of Uchguli village, Mestia municipality, with both the European and Ukrainian method showed the highest infestation, up to 15 resting spores /g soil. In villages Uchkho, Dzirkvadzeebi, Rakvta, and Skvana, Khulo municipality, 4-7 resting spores/ g soil were detected. Soil samples, collected from villages of Vashlovani, Kotchalidzebi, Diakonidzeebi, Danisparauli, and Tabakhmela, contained only 3 resting spores/g soil. In soil samples, collected from villages of Didajara, Mtisthina, Dekanashvilebi, Joidzeebi, Mekeidzeebi, Thilvana of Khulo municipality and Latali village of Mestia municipality, both methods detected only 2 resting spores/g soil. In the samples collected from villages of Vanadzeebi, Kurduli, Mintadzeebi, Tsablana, and Purchukauli, Khulo municipality only a single resting spore was detected by both methods.

For 6 out of 22 samples ( $27 \%$ ) with low numbers of resting spores detected the $\mathrm{NaI}$ method was statistically significantly less efficient (42-70\%), see Table 2.

\section{DISCUSSION}

Many methods to extract and detect resting spores of S. endobioticum have been proposed and used over the years (see Table 3, Obidiegwu JE et al, 2014, van Leeuwen GCM et al, 2005). Many chemical compounds in these methods, such as dibromoethane, chloroform, and especially carbon tetrachloride - are potent toxins 
and/or carcinogens, and should preferably be avoided in routine detection.

The current EPPO standard PM 7/28(2) (2017) on $S$. endobioticum diagnosis, one of the recommended methods to extract potato wart resting spores is adapted from van Leeuwen GCM et al, 2005 and uses kaolin and $\mathrm{CaCl}_{2}$ with a specific weight of 1.4 (EPPO Standard PM 7/28(2), 2017 and Table 3). This method was largely followed in our study and was compared with a method using concentrated solutions of $\mathrm{NaI}$ (s.w. 1.2

Table 1. The efficiency of two methods, using $\mathrm{NaI}$ and kaolin/ $\mathrm{CaCl} 2$ respectively to detect potato wart resting spores and the total soil organic matter in 11 Ukrainian infested plots

\begin{tabular}{|c|c|c|c|c|c|c|}
\hline $\begin{array}{c}\text { Name } \\
\text { of the infested plot }\end{array}$ & $\begin{array}{l}\text { North latitude, } \\
\text { N/East } \\
\text { longitude, E }\end{array}$ & $\begin{array}{c}\text { Meter } \\
\text { above } \\
\text { sea level }\end{array}$ & SOM, \% & $\begin{array}{l}\text { No. of } \\
\text { resting } \\
\text { spores. NaI } \\
(\mathrm{M} \pm \mathrm{m})\end{array}$ & $\begin{array}{c}\text { No. of } \\
\text { resting } \\
\text { spores } \\
\text { kaolin/ } \\
\mathrm{CaCl}_{2} \\
(\mathrm{M} \pm \mathrm{m})\end{array}$ & $\begin{array}{l}\text { Method } \\
\text { efficiency, } \\
\%\end{array}$ \\
\hline $\begin{array}{l}\text { Berehomet town } \\
\text { Vyzhnytsia district, } \\
\text { Chernivtsi region }\end{array}$ & $\begin{array}{l}48^{\circ} 10^{\prime} 00^{\prime \prime} / \\
25^{\circ} 19^{\prime} 48^{\prime \prime}\end{array}$ & 460 & $2.3 \pm 0.03$ & $58.3 \pm 0.06$ & $56.1 \pm 0.03$ & 96.5 \\
\hline $\begin{array}{l}\text { Toraky village } \\
\text { Putyla District } \\
\text { Chernivtsi Region }\end{array}$ & $\begin{array}{l}48^{\circ} 01^{\prime} 92^{\prime \prime /} \\
25^{\circ} 066^{\prime} 77^{\prime \prime}\end{array}$ & 595 & $2.4 \pm 0.03$ & $54.2 \pm 0.05$ & $52.2 \pm 0.03$ & 96.9 \\
\hline $\begin{array}{l}\text { Parkulyna village } \\
\text { Putyla district, } \\
\text { Chernivtsi region }\end{array}$ & $\begin{array}{l}47^{\circ} 99^{\prime} 18^{\prime \prime} / \\
25^{\circ} 12^{\prime} 59^{\prime \prime}\end{array}$ & 939 & $2.0 \pm 0.03$ & $52.3 \pm 0.03$ & $51.2 \pm 0.06$ & 98.0 \\
\hline $\begin{array}{l}\text { Storozhynets town } \\
\text { Chernivtsi Region }\end{array}$ & $\begin{array}{l}48^{\circ} 09^{\prime} 27^{\prime \prime} / \\
25^{\circ} 42^{\prime} 57^{\prime \prime}\end{array}$ & 353 & $2.0 \pm 0.06$ & $65.3 \pm 0.08$ & $65.0 \pm 0.03$ & 99.8 \\
\hline $\begin{array}{l}\text { Maidan village } \\
\text { Mizhhirya District } \\
\text { Zakarpattia Region }\end{array}$ & $\begin{array}{l}48^{\circ} 36^{\prime} 05^{\prime \prime} / \\
23^{\circ} 28^{\prime} 29^{\prime \prime}\end{array}$ & 495 & $2.1 \pm 0.03$ & $41.2 \pm 0.06$ & $40.2 \pm 0.05$ & 97.3 \\
\hline $\begin{array}{l}\text { Torun village } \\
\text { Mizhhirya District } \\
\text { Zakarpattia Region }\end{array}$ & $\begin{array}{l}48^{\circ} 52^{\prime} 52^{\prime \prime} / \\
23^{\circ} 50^{\prime} 65^{\prime \prime}\end{array}$ & 662 & $2.0 \pm 0.07$ & $43.1 \pm 0.05$ & $43.0 \pm 0.06$ & 99.7 \\
\hline $\begin{array}{l}\text { Surupy village } \\
\text { Rakhiv District } \\
\text { Zakarpattia Region }\end{array}$ & $\begin{array}{l}48^{\circ} 00^{\prime} 42^{\prime \prime} / \\
24^{\circ} 20^{\prime} 19^{\prime \prime}\end{array}$ & 419 & $2.0 \pm 0.06$ & $53.1 \pm 0.06$ & $52.9 \pm 0.07$ & 99.1 \\
\hline $\begin{array}{l}\text { Yasinia village } \\
\text { Rakhiv District } \\
\text { Zakarpattia Region }\end{array}$ & $\begin{array}{l}48^{\circ} 15^{\prime} 37^{\prime \prime} / \\
24^{\circ} 21^{\prime} 32^{\prime \prime}\end{array}$ & 699 & $2.2 \pm 0.03$ & $65.1 \pm 0.07$ & $63.3 \pm 0.06$ & 96.9 \\
\hline $\begin{array}{l}\text { Iltsi village } \\
\text { Verkhovyna district, } \\
\text { Ivano-Frankivsk region }\end{array}$ & $\begin{array}{l}48^{\circ} 06^{\prime} 47^{\prime \prime} / \\
24^{\circ} 40^{\prime} 54^{\prime \prime}\end{array}$ & 780 & $2.6 \pm 0.03$ & $41.6 \pm 0.04$ & $40.7 \pm 0.07$ & 97.5 \\
\hline $\begin{array}{l}\text { Bystrets village } \\
\text { Verkhovyna district, } \\
\text { Ivano-Frankivsk region }\end{array}$ & $\begin{array}{l}48^{\circ} 07^{\prime} 26^{\prime \prime} / \\
24^{\circ} 41^{\prime} 22^{\prime \prime}\end{array}$ & 786 & $2.7 \pm 0.06$ & $46.3 \pm 0.08$ & $45.1 \pm 0.05$ & 98.6 \\
\hline $\begin{array}{l}\text { Turka town } \\
\text { Lviv Region }\end{array}$ & $\begin{array}{l}49^{\circ} 09^{\prime} 10^{\prime \prime} / \\
23^{\circ} 02^{\prime} 11^{\prime \prime}\end{array}$ & 574 & $2.0 \pm 0.06$ & $49.1 \pm 0.3$ & $49.0 \pm 0.04$ & 99.9 \\
\hline $\mathrm{LSD}_{0.5}$ & & & 0.05 & 0.07 & 0.07 & \\
\hline
\end{tabular}

Note. $\mathrm{SOM}=$ soil organic matter 
Table 2. The efficiency of two methods, using kaolin/ $/ \mathrm{CaCl}_{2}$ and $\mathrm{NaI}$, respectively to detect potato wart resting spores and the content of the total soil organic matter in 22 Georgian infested plots

\begin{tabular}{|c|c|c|c|c|c|c|}
\hline $\begin{array}{c}\text { Name } \\
\text { of the infested plot }\end{array}$ & $\begin{array}{c}\text { North latitude, } \\
\text { N/East } \\
\text { longitude, E }\end{array}$ & $\begin{array}{c}\text { Meter } \\
\text { above } \\
\text { sea level }\end{array}$ & SOM, \% & $\begin{array}{l}\text { No. of } \\
\text { resting } \\
\text { spores. NaI } \\
(\mathrm{M} \pm \mathrm{m})\end{array}$ & $\begin{array}{c}\text { No. of } \\
\text { resting } \\
\text { spores } \\
\text { kaolin/ } \\
\mathrm{CaCl}_{2} \\
(\mathrm{M} \pm \mathrm{m})\end{array}$ & $\begin{array}{c}\text { Method } \\
\text { efficiency, } \\
\%\end{array}$ \\
\hline \multicolumn{7}{|c|}{ Khulo municipality, Adjara } \\
\hline Didajara village & $\begin{array}{l}41^{\circ} 39^{\prime} 57^{\prime \prime} / \\
42^{\circ} 20^{\prime} 47^{\prime \prime}\end{array}$ & 800 & $3.3 \pm 0.03$ & $1.7 \pm 0.93$ & $1.6 \pm 0.12$ & 94.1 \\
\hline Mtisthina village & $\begin{array}{l}41^{\circ} 40^{\prime} 27^{\prime \prime} / \\
42^{\circ} 22^{\prime} 05^{\prime \prime}\end{array}$ & 800 & $3.6 \pm 0.06$ & $1.7 \pm 0.47$ & $1.5 \pm 0.09$ & 88.2 \\
\hline Vanadzeebi village & $\begin{array}{l}41^{\circ} 42^{\prime} 02^{\prime \prime} / \\
42^{\circ} 23^{\prime} 06^{\prime \prime}\end{array}$ & 800 & $3.1 \pm 0.03$ & $1.3 \pm 0.47$ & $1.2 \pm 0.12$ & 92.2 \\
\hline Vashlovani village, Alme & $\begin{array}{l}41^{\circ} 38^{\prime} 04^{\prime \prime} / \\
42^{\circ} 18^{\prime} 02^{\prime \prime}\end{array}$ & 800 & $3.4 \pm 0.06$ & $2.7 \pm 0.46$ & $2.5 \pm 0.06$ & 92.6 \\
\hline Dekanashvilebi village & $\begin{array}{l}41^{\circ} 39^{\prime} 04^{\prime \prime} / \\
42^{\circ} 18^{\prime} 20^{\prime \prime}\end{array}$ & 1000 & $3.6 \pm 0.03$ & $1.7 \pm 0.47$ & $1.6 \pm 0.09$ & 94.1 \\
\hline Kurduli village & $\begin{array}{l}41^{\circ} 42^{\prime} 03^{\prime \prime} / \\
42^{\circ} 22^{\prime} 43^{\prime \prime}\end{array}$ & 1000 & $3.9 \pm 0.03$ & $0.7 \pm 0.06$ & $0.3 \pm 0.12$ & 42.8 \\
\hline Joidzeebi village & $\begin{array}{l}41^{\circ} 40^{\prime} 26^{\prime \prime} / \\
42^{\circ} 19^{\prime} 25^{\prime \prime}\end{array}$ & 1000 & $3.8 \pm 0.06$ & $2.3 \pm 0.27$ & $2.0 \pm 0.06$ & 86.9 \\
\hline Kotchalidzebi village & $\begin{array}{l}41^{\circ} 38^{\prime} 35^{\prime \prime} / \\
42^{\circ} 26^{\prime} 19^{\prime \prime}\end{array}$ & 1250 & $3.1 \pm 0.03$ & $3.0 \pm 0.44$ & $2.9 \pm 0.27$ & 96.7 \\
\hline Mekeidzeebi village & $\begin{array}{l}41^{\circ} 42^{\prime} 25^{\prime \prime} / \\
42^{\circ} 23^{\prime} 37\end{array}$ & 1200 & $3.7 \pm 0.03$ & $1.7 \pm 0.47$ & $1.2 \pm 0.07$ & 70.6 \\
\hline Diakonidzeebi village & $\begin{array}{l}41^{\circ} 39^{\prime} 32^{\prime \prime} / \\
42^{\circ} 20^{\prime} 11^{\prime \prime}\end{array}$ & 800 & $3.8 \pm 0.06$ & $3.3 \pm 0.56$ & $2.8 \pm 0.09$ & 84.8 \\
\hline Mintadzeebi village & $\begin{array}{l}41^{\circ} 42^{\prime} 43^{\prime \prime} / \\
42^{\circ} 22^{\prime} 54^{\prime \prime}\end{array}$ & 1200 & $3.3 \pm 0.03$ & $0.7 \pm 0.27$ & $0.6 \pm 0.12$ & 85.7 \\
\hline Tsablana village & $\begin{array}{l}41^{\circ} 35^{\prime} 05^{\prime \prime} / \\
42^{\circ} 20^{\prime} 49^{\prime \prime}\end{array}$ & 1200 & $3.4 \pm 0.06$ & $0.7 \pm 0.17$ & $0.6 \pm 0.12$ & 85.5 \\
\hline Purchukauli village & $\begin{array}{l}41^{\circ} 33^{\prime} 41^{\prime \prime} / \\
42^{\circ} 27^{\prime} 00^{\prime \prime}\end{array}$ & 1200 & $3.8 \pm 0.03$ & $0.7 \pm 0.12$ & $0.3 \pm 0.06$ & 42.8 \\
\hline Skvana village & $\begin{array}{l}41^{\circ} 32^{\prime} 58^{\prime \prime} / \\
42^{\circ} 29^{\prime} 09^{\prime \prime}\end{array}$ & 1291 & $3.9 \pm 0.06$ & $7.0 \pm 0.81$ & $4.3 \pm 0.06$ & 61.4 \\
\hline Rakvta village & $\begin{array}{l}41^{\circ} 34^{\prime} 11^{\prime \prime} / \\
42^{\circ} 28^{\prime} 58^{\prime \prime}\end{array}$ & 1200 & $3.2 \pm 0.03$ & $5.0 \pm 0.43$ & $4.8 \pm 0.06$ & 96.0 \\
\hline Danisparauli village & $\begin{array}{l}41^{\circ} 38^{\prime} 56^{\prime \prime} / \\
42^{\circ} 28^{\prime} 11^{\prime \prime}\end{array}$ & 1520 & $3.6 \pm 0.03$ & $2.7 \pm 0.46$ & $2.2 \pm 0.03$ & 81.4 \\
\hline Tabakhmela village & $\begin{array}{l}41^{\circ} 37^{\prime} 51^{\prime \prime} / \\
42^{\circ} 24^{\prime} 48^{\prime \prime}\end{array}$ & 1200 & $3.3 \pm 0.06$ & $3.3 \pm 0.56$ & $3.1 \pm 0.06$ & 93.9 \\
\hline Uchkho village & $\begin{array}{l}41^{\circ} 40^{\prime} 56^{\prime \prime} / \\
42^{\circ} 18^{\prime} 51^{\prime \prime}\end{array}$ & 1083 & $3.3 \pm 0.03$ & $4.3 \pm 0.41$ & $4.2 \pm 0.06$ & 97.6 \\
\hline Dzirkvadzeebi village & $\begin{array}{l}41^{\circ} 40^{\prime} 56^{\prime \prime} / \\
42^{\circ} 18^{\prime} 51^{\prime \prime}\end{array}$ & 1200 & $3.4 \pm 0.03$ & $4.3 \pm 0.47$ & $4.1 \pm 0.06$ & 95.3 \\
\hline Thilvana village & $\begin{array}{l}41^{\circ} 32^{\prime} 48^{\prime \prime} / \\
42^{\circ} 31^{\prime} 20^{\prime \prime}\end{array}$ & 1440 & $3.7 \pm 0.03$ & $1.7 \pm 0.07$ & $1.3 \pm 0.03$ & 76.4 \\
\hline
\end{tabular}




\begin{tabular}{|c|c|c|c|c|c|c|}
\hline $\begin{array}{c}\text { Name } \\
\text { of the infested plot }\end{array}$ & $\begin{array}{c}\text { North latitude, } \\
\text { N/East } \\
\text { longitude, E }\end{array}$ & $\begin{array}{c}\text { Meter } \\
\text { above } \\
\text { sea level }\end{array}$ & SOM, $\%$ & $\begin{array}{l}\text { No. of } \\
\text { resting } \\
\text { spores. NaI } \\
(\mathrm{M} \pm \mathrm{m})\end{array}$ & $\begin{array}{l}\text { No. of } \\
\text { resting } \\
\text { spores } \\
\text { kaolin/ } \\
\mathrm{CaCl}_{2} \\
(\mathrm{M} \pm \mathrm{m})\end{array}$ & $\begin{array}{c}\text { Method } \\
\text { efficiency, } \\
\%\end{array}$ \\
\hline \multicolumn{7}{|c|}{ Mestia municipality } \\
\hline Uchguli village & $\begin{array}{l}42^{\circ} 55^{\prime} 00^{\prime \prime} / \\
43^{\circ} 00^{\prime} 00^{\prime \prime}\end{array}$ & 2200 & $3.6 \pm 0.06$ & $14.7 \pm 1.06$ & $14.3 \pm 0.23$ & 97.3 \\
\hline Latali village & $\begin{array}{l}43^{\circ} 00^{\prime} 18^{\prime \prime} / \\
42^{\circ} 38^{\prime} 51^{\prime \prime}\end{array}$ & 1340 & $3.9 \pm 0.03$ & $1.7 \pm 0.07$ & $0.8 \pm 0.03$ & 47.1 \\
\hline \multicolumn{3}{|l|}{$\mathrm{LSD}_{0.5}$} & 0.06 & 0.08 & \multicolumn{2}{|l|}{0.06} \\
\hline
\end{tabular}

Note. $\mathrm{SOM}=$ soil organic matter.

and 1.4). This method was developed and introduced in the regional Ukrainian phytosanitary laboratories (Zelya AH, 2005). When comparing these two methods in the present study (and experience in the past) it was shown that the method using $\mathrm{NaI}$ did not work as well for soils with high organic content as the one using kaolin/ $\mathrm{CaCl}_{2}$, so may be infested areas may have gone undetected. Therefore, it is proposed to use in future the EPPO Standard method (EPPO Standard PM $7 / 28(2), 2017)$, using kaolin and $\mathrm{CaCl}_{2}$ in the Ukrainian and Georgian (regional) laboratories.

The results obtained in the present study further indicate a possible tendency of a decrease in inoculum density in soils of some infested plots in Ukraine. For instance, in 2012 Zelya AH et al (2012) found an inoculum density in the Bukovyna plots to be within the range of 42-74 resting spores/g soil, in 2020 it was 40-65 resting spores/g soil. The current infested area in area of Bukovyna is 0.63 ha which is 7.56 ha $(92.3 \%)$ less than in 2012 when it was 8.19 ha (Zelya AH et al, 2020a; https://dpss.gov.ua/)

Similarly in the regions of Ivano-Frankivsk, Lviv, and Zakarpattia Regions inoculum density was 8-28 resting spores/g soil in Perechyn, Svaliava, and Velykyi Bereznyi Districts (Zelya A H et al, 2011) and 56-76 resting spores in Mizhhirya and Rakhiv Districts, respectively (Fig. 1). In 2020, the inoculum level in these two latter districts decreased to 42-65 resting spores/g soil (Zelya A H et al, 2020a). Some potato wart plots could be descheduled from quarantine measures because resting spores were not detected anymore for 10 years. For example, plots in the Perechyn, Svaliava, and Velykyi Bereznyi Districts. In the Malynska bila, Kalynivska, Dyvo, Chervona ruta areas and plots farmers were allowed again to grow resistant potato varieties. The area under quarantine measures for $S$. endobioticum in the Zakarpattia Region as a whole decreased by $34 \%$ as compared with 2011 and amounted to 2,212.48 ha in 2020 (https:// dpss.gov.ua/). However further spread of potato wart and its causal organism $S$. endobioticum still takes place in Ukraine: for instance, in 2020 the specialists of the State Service of Ukraine on Food Safety and Consumer Protection in Lviv Region detected a new infested area in Darnych village of Kamyanka-Buzka District, of 77.5 ha.

Since the first detection of S. endobioticum in Ukraine in 1938 until the 1990s, there was a slow expansion of the infested areas due to considerable atmospheric precipitation and flooding, caused by the latter. Especially rapid increase was noted in the 1990 s, when $S$. endobioticum was detected at its peak in 1996 in 1,674 villages from 19 Ukrainian regions, at 86,434 household farms in 110 districts with the total area of over 12,134 ha (Melnyk PO, 2003). Starting with 2000, level of infestation, however, has been clearly and constantly decreasing due to severe quarantine measures and use of resistant potato varieties. In 2011, the disease agent was detected in 13 Ukrainian regions at the area of 8,307.2 ha (https://dpss.gov.ua/). In the recent decade, the area of potato wart infestation has decreased again by $72.2 \%$ as compared with 2011 to $2,307.2$ ha. When compared to 1996, when Ukraine was on the peak of the disease spreading, the area has decreased by $80.9 \%$. As of January 01,2021 , the disease was present in 4 regions, 21 districts, 205 villages, 7,796 household 
farms, in the total area of 2,307.2 ha (Fig. 2) (https:// dpss.gov.ua/).

At the beginning of the $21^{\text {st }}$ century, the quarantine disease potato wart has been actively controlled throughout Ukraine. The cultivation of resistant potato varieties, allowed complete elimination of the sources of infection at the collective farms of Vinnytsia, Zakarpattia, Ivano-Frankivsk, Lviv, and Chernivtsi Regions. The soil was disinfected according to the recommendations of the scientists of the Ukrainian Scientific Research Plant Quarantine Station (USRPQS), IPP NAAS, and the specialists of regional plant quarantine inspectorates using carbamide, $1.5 \mathrm{~kg} / \mathrm{m}^{2}$, and/or a mixture of carbamide, $0.075 \mathrm{~kg} / \mathrm{m}^{2}$ and copper sulfate, $0.025 \mathrm{~kg} / \mathrm{m}^{2}$ (Zelya A H et al, 2012). The resistant po- tato varieties used in the eradication campaign till so far were Bozhedar, Luhovska Skarbnytsia, Slovianka, and Vodohrai.

Descheduling took place on plots were both the common pathotype 1(D1) and aggressive pathotypes occurred. Detection and control of potato wart is performed according to the methodological recommendations, elaborated by the scientists of USRPQS, IPP NAAS, and the specialists of the State Service of Ukraine on Food Safety and Consumer Protection (Zelya A H et al, 2006). Prior to 1988, the common 1(D1) and 7 aggressive pathotypes of potato wart were identified. In 2003, Melnyk PO (2003) reported finding one common and only four aggressive pathotypes. This situation remains up till today (Zelya A G et al, 2020b). In

Table 3. Extraction and detection methods for Synchytrium endobioticum resting spores in soil ${ }^{1)}$

\begin{tabular}{|c|c|}
\hline Method & Citation \\
\hline $\begin{array}{l}\text { Separation of sporangia from soil particles based on different specific } \\
\text { gravity in chloroform }\end{array}$ & $\begin{array}{l}\text { Glynne (1926), Pratt (1976), Hampson and } \\
\text { Thompson (1977), Hampson and Robertson (1995) }\end{array}$ \\
\hline Extraction with carbon tetrachloride & Sharikov (1954) \\
\hline Wet sieving using electromagnetic shaker aided by chloroform floatation & Hampson and Coombes (1996) \\
\hline Soil extraction with the non-ionic detergent Triton X100 & Laidlaw (1985) \\
\hline $\begin{array}{l}\text { Substitution of chloroform by dibromomethane Nelson \& Olsen also } \\
\text { used oil, and fluoric acid for sand removal }\end{array}$ & Nelson and Olsen (1964); Vladimirskaja (1982) \\
\hline Extraction in water and sedimentation using sodium sulphate & Marcus (1969), Mygind (1954; 1961) \\
\hline Extraction with a mixture of carbon tetrachloride and ether & Golik (1973) \\
\hline Extraction with $25 \%$ of hydrofluoric acid & Potoček (1977) \\
\hline Extraction with carbon tetrachloride & Fedotova (1982) \\
\hline $\begin{array}{l}\text { Extraction with } 6 \mathrm{M} \text { sodium chloride, staining } 10^{-6} \mathrm{~g} / \mathrm{ml} \text { ethidium } \\
\text { bromide or ANS (1-anilino-naphthalene- } 8 \text {-sulfonate) } 10^{-3} \mathrm{~g} / \mathrm{ml}\end{array}$ & Yakovleva (1985) \\
\hline $\begin{array}{l}\text { Extraction with } 70 \% \text { solution of sucrose and fluorescent acridine } \\
\text { orange dye for viability check }\end{array}$ & Surnakova (1992) \\
\hline $\begin{array}{l}\text { Extraction with } 40 \% \text { potassium iodide from air dried soil after sieving, } \\
\text { with vacuum filtration of the supernatant }{ }^{2)}\end{array}$ & Putnam and Sindermann (1994) \\
\hline $\begin{array}{l}\text { Density gradients with potassium/sodium salt on air dried soil after } \\
\text { sieving }\end{array}$ & Zeyla and Melnik (1998) \\
\hline Extraction with calcium chloride and zinc sulphate & van Leeuwen et al. (2005) \\
\hline Zonal centrifugation & Wander et al. (2007) \\
\hline Polymerase chain reaction (PCR) using species-specific primers & $\begin{array}{l}\text { Niepold and Stachewicz (2004), van den Boogert et } \\
\text { al. (2005), van Gent-Pelzer et al. (2010) }\end{array}$ \\
\hline Microarray-based hybridization & Abdullahi et al. (2005) \\
\hline $\begin{array}{l}\text { Three options: Sieving method A, using chloroform (Pratt, 1976). } \\
\text { Sieving method B (adapted from van Leeuwen, et al., 2005), using } \\
\text { kaolin and } \mathrm{CaCl}_{2} \text { and Zonal centrifuge technique (Wander et al., 2007), } \\
\text { apart from bioassay }\end{array}$ & EPPO Standard PM 7/28(2) (2017) \\
\hline
\end{tabular}

Note. ${ }^{1)}$ Adapted and extended from Obidiegwu et al, 2014. ${ }^{2)}$ NB: for their method they cite Hampson, M.C. and P.R. Thompson. 1977. A quantitative method to examine large numbers of soil samples for Synchytrium endobioticum, the cause of potato wart disease. Plant and Soil 46:659-664. Remarkably the latter authors did not use KI but chloroform for extraction. 


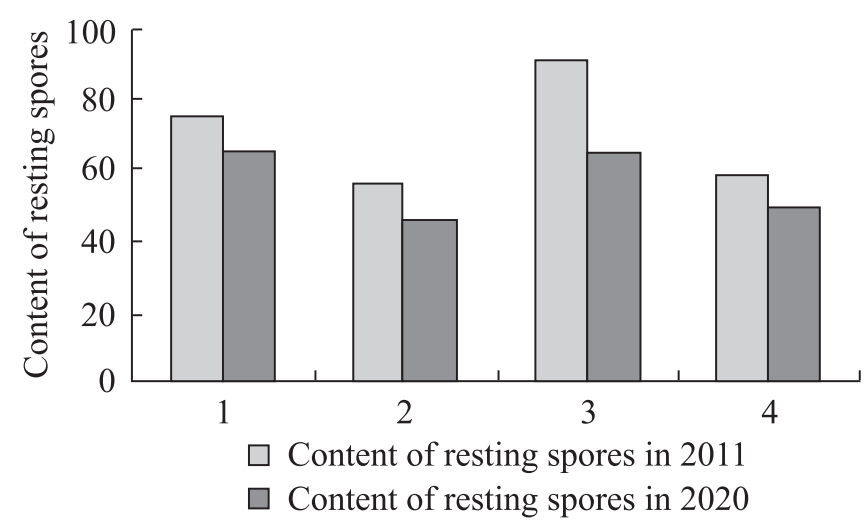

Fig. 1. Tendency of decrease in number of resting spores (per gram of soil) of $S$. endobioticum in infested plots over the years 2011-2020: 1 - the content of potato wart resting spores in Chernivtsi Region; 2 - the content of potato wart resting spores in Ivano-Frankivsk Region; 3 - the content of potato wart resting spores in Zakarpattia Region; 4 - the content of potato wart resting spores in Lviv Region

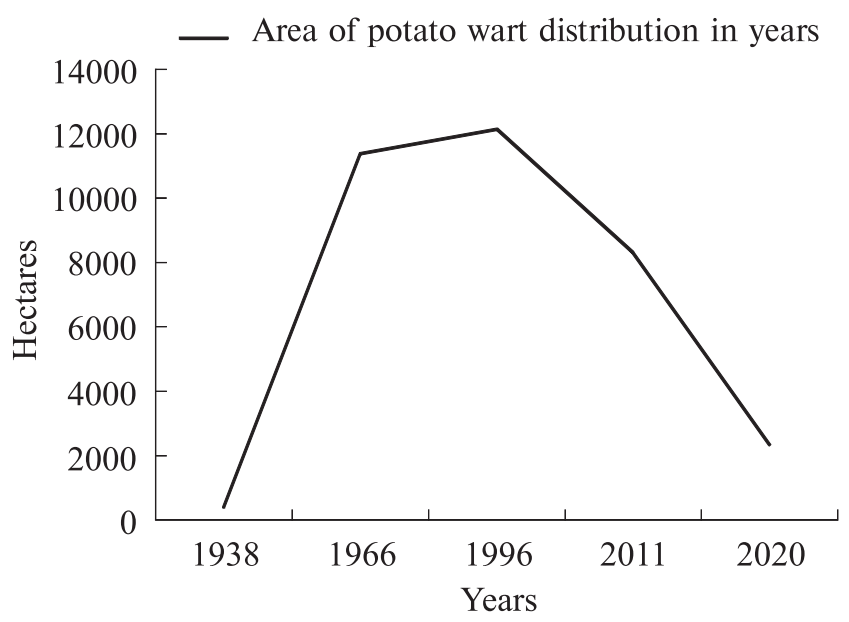

Fig. 2. The dynamics of potato wart distribution in Ukraine (1938-2020) (based on former USSR and Ukrainian NPPO historical survey data)

recent years, there has been successful elimination of potato wart in some areas of Zakarpattia region due to imposing quarantine measures: in villages of Mizhhirya, Verkhnii Bystryi, Soimy, where aggressive pathotype 11(M1) - Mizhhirskyi was widespread; in villages of Dilove, Kostylivka, where it was aggressive pathotype 13(R2) - Rakhivskyi; in villages of Kvasy, Lazeshchyna and Chorna Tysa, where it was aggressive pathotype 18(Ya) - Yasinivskyi (Zelya AG et al, 2020b).

In Ivano-Frankivsk Region, where prior to 1988 there had been three aggressive pathotypes of the disease agent: 20(Sh) - Sheshorskyi, 21(S) - Sokolivskyi and 22(B) - Bystrytskyi aggressive pathotype, there has been successful elimination of the plots, where aggressive pathotypes 20Sh and $21 \mathrm{~S}$ were widespread and as per 2020, only the 22(B) - Bystrytskyi aggressive pathotype was identified. The total area of fields, infected with the disease in Ivano-Frankivsk Region, was 16.45 ha in 2020 (Zelya AH et al, 2020a; https:// dpss.gov.ua/).

The determination of inoculum level in the 11 plots in Georgia was performed for the first time after the first reporting of potato wart in 2014 (Gorgiladze L et al, 2014).

In 2020, potato wart infested plots were found in the villages of Uchkho, Dzirkvadzeebi, Rakvta, and Skvana of Khulo municipality (Ghoghoberidze S, 2020). The pathotype of $S$. endobioticum involved, was identified as $38(\mathrm{~N})$ - Nevşehir pathotype, widespread in Turkey Çakir E, Demirci F (2017). Turkey borders only $8 \mathrm{~km}$ from the closest Georgian plot. It may be possible that $S$. endobioticum has been introduced into Georgia via the purchase of infected (seed) potatoes from Turkey.

In Georgian potato wart plots, the inoculum level of the resting spores was found to be 4-20 times lower than in the Ukrainian plots, which may be caused by differences in climate, and other geographic conditions and/or differences in soil types and agricultural practice.

As an outcome of this limited survey and comparison of two extraction methods we plan to do a more extensive survey, using the EPPO method and to do a full harmonization experiment to identify the Ukrainian and Georgian pathotypes based on the international (European) potato variety test assortment. Furthermore, we will investigate the possibility of the application of molecular methods for detection (EPPO PM 7/28(2), 2017; Tsvetkova YV and Yakovleva VA, 2021).

\section{CONCLUSIONS}

Joint studies between Ukraine and Georgia, conducted in 2018-2020, to determine the inoculum level and persistence of Synchytrium endobioticum resting spores in plots and soils in Ukraine and Georgia, demonstrated different levels of inoculum with resting spores of $S$. endobioticum in these countries (40-65 resting spores/g soil to $1-15$ resting spores/g soil, respectively).

The inspection of potato wart plots in Chernivtsi, Ivano-Frankivsk, Zakarpattia, and Lviv Regions of Ukraine in 2018-2020 demonstrated a high level of disease progression at the farms, where susceptible potato varieties were cultivated. The inoculum within 
the inspected infested plots was 40-65 resting spores/g soil, which was less than in 2011. As for the general national scale, in recent 9 years (2011-2020) there has been a decrease by $72.2 \%$ in the distribution area of S. endobioticum in Ukraine and by $9.8 \%$ - in the level of inoculum in the infested plots.

In the majority of the inspected Georgian plots the inoculum level was low (1-7 resting spores/g soil and only in one village (Uchguli, Mestia municipality) their level amounted to 15 resting spores/g soil.

The method of applying sodium iodide was found to be comparable to the method of applying kaolin and $\mathrm{CaCl}_{2}$ under conditions of moderate to high inoculum levels (15-65 resting spores per g soil) but the latter method was more efficient under conditions of high content of organic matter and very low inoculum level ( $<5$ resting spores/g soil).

The study was conducted within the framework of the creative cooperation agreement, signed by the Ukrainian Scientific Research Plant Quarantine Station, IPP NAAS of Ukraine, and the Institute of Phytopathology and Biodiversity of the Batumi Shota Rustaveli State University, Georgia.

Adherence to ethical principles. All experiments described in this paper were non animal based.

Conflict of interests. The authors declare the absence of any conflicts of interests.

Financing. This study was not financed by any specific grant from financing institutions in the state, commercial or non-commercial sectors.

\section{Ефективність виявлення зимуючих зооспорангісв Synchytrium endobioticum (рак картоплі) в осередках хвороби України та Грузії}
А. Г.Зеля ${ }^{*}$, Л. А.ЯНсе ${ }^{3}$, Я. Д. Янсе ${ }^{3}$, С. Е. Гогоберідзе ${ }^{2}$, Г. В. Зеля ${ }^{1}$, Р. О. Кордулян ${ }^{1}$, 3. В. Сіхарулідзе ${ }^{2}$

${ }^{1}$ Українська науково-дослідна станція карантину рослин Інститут захисту рослин НААН,

Вул. Наукова, 1. с. Бояни Новоселицького району

Чернівецької області, Україна

${ }^{2}$ Інститут фітопатології та біорізноманіття

Батумського державного університету ім. Шота Руставелі,

Вул. Тавісуплеба, 90, Кобулеті, Грузія, 6200

${ }^{3}$ Інститут захисту рослин НАAН,

Вул. Васильківська, 33, Київ, Україна, 03022

e-mail: avrelia.zelya@gmail.com*; liliya.janse@gmail.com; j.janse6@gmail.com; sof.gogoberidze@gmail.com; georgetrexnauk@gmail.com; kordulyanroman@gmail.com; zsikharulidze@ymail.com
Мета. Визначити поширення та виживання зимуюючих зооспорангіїв Synchytrium endobioticum у грунті під час орієнтаційного обстеження заражених ділянок вирощування картоплі в Україні та Грузії; визначити ефективність екстракції з грунтових зразків зимуюючих зооспорангіїв $S$. endobioticum за використання методу флотації у розчині натрію йодистого (Zelya et al, 2005) за використання каоліну та кальцію хлористого $\left(\mathrm{CaCl}_{2}\right)$ (EPPO Standard PM 7/28(2) (2017). Методи. Обстеження полів на виявлення збудника раку картоплі у 22 вогнищах Грузії проводили за стандартом ЕРРО РМ 3/59(3) (2017), у 11 вогнищах України - згідно методичних рекомендацій з відбору проб у процесі карантинного огляду та експертизи (Omeluta VP et al, 1996). Екстракцію зимуючих зооспорангіїв збудника проводили за використання каоліну та $\mathrm{CaCl}_{2}$ (ЕРPО PM 7/28(2) 2017) флотацією у розчині натрію йодистого (Zelya et al 2005). Визначення вмісту органічних речовин у зразках грунту, відібраних у вогнищах раку картоплі в Україні та Грузії, проводили згідно «Методу лабораторного визначення вмісту органічних речовин» (Jankauskas B et al, 2006). Ревізію стану виявлених вогнищ збудника раку картоплі здійснювали на підставі даних власних обстежень національних фітосанітарних служб (https:// dpss.gov.ua; http://agr.georgia.gov). Результати досліджень опрацьовували за використання статистичного аналізу програмного пакету Statistica 5. Результати. Встановлено, що при низькому та високому рівнях органічної речовини у зразках грунту $(2,0-2,7 \%$ i 3,1-3,9 \% відповідно) та помірної до високої щільності зимуючих зооспорангієв $S$. endobioticum у грунті (3-15 до 41-65 шт/г грунту відповідно) не було істотних відмінностей в ефективності двох досліджуваних методів екстракції: флотації у розчині $\mathrm{NaI}$ та застосування каоліну $/ \mathrm{CaCl}_{2}$. Однак при малій кількості зимуючих зооспорангієв, наявних у грунті (1-2 шт/г грунту), ефективність методу 3 використанням $\mathrm{NaI}$ статистично достовірно знижувалась на 20-30\% на відміну від методу з використанням каоліну $/ \mathrm{CaCl}_{2}$. Порівняно високий рівень чисельності зимуючих зооспорангієв $S$. endobioticum виявлено на 11 досліджених ділянках 4 областей України: 41-46 шт/г грунту в Івано-Франківській області, 49 - у Львівській, 40-65 - у Закарпатській та 52-65 - у Чернівецькій областях. Більшість із 22 досліджених ділянок Грузії показали низький рівень чисельності зимуючих зооспорангієв $S$. endobioticum в грунті (1-7 шт/г грунту), і лише в одному селі їх рівень становив 15 шт/г грунту (село Ушгулі, муніципалітет Местія). Висновки. Встановлено, що використання досліджуваних методів екстракції: флотації у розчині $\mathrm{NaI}$ та застосування каоліну/ $\mathrm{CaCl}_{2}$ було порівняним для зразків грунту від помірного до високого рівня чисельності зимуючих зооспорангієв S. endobioticum (15-65 шт/г грунту), проте останній метод був більш ефективним за умов високого вмісту органічних речовин і дуже низької чисельності патогену 
в грунті ( $<5$ зимуючих зооспорангієв/г грунту). Зроблено висновок про доцільність впровадження в практику регіональних і національних лабораторій обох країн стандартного методу ЕРРО РМ 7/28(2) (2017), що передбачає використання каоліну та $\mathrm{CaCl}_{2}$. Показано, що на заражених ділянках грунтів в Україні щільність зимуючих зооспорангієв збудника раку картоплі була у 4-20 разів вище, ніж у вогнищах цієї хвороби в Грузії, що, можливо, було спричинено різницею кліматичних та інших географічних умов та/або відмінності у типах грунтів і сільськогосподарської практики. У загальнодержавному масштабі за останні 9 років (20112020 рр.) в Україні спостерігається зменшення на 72,2 \% площ заражених збудником раку картоплі грунтів та на 9,8 \% - щільності зимуючих зооспорангієв S. endobioticum у грунті.

Ключові слова: рак картоплі, зимуючі зооспорангії, екстракція, флотація, органічні речовини.

\section{REFERENCES}

Abdullahi I, Koerbler M, Stachewicz H, Winter S. (2005) The 18SrDNA sequence of Synchytrium endobioticum and its utility in microarrays for the simultaneous detection of fungal and viral pathogens of potato. Appl. Microbiol. Biotechnol. 68:368-375.

Baayen RP, Cochius G, Hendriks H, Meffert JP, Bakker J, Bekker M, van den Boogert PHJF, Stachewicz H, van Leeuwen GCM. (2006) History of potato wart disease in Europe - a proposal for harmonisation in defining pathotypes. Europ. J. Plant Pathol. 116:21-31. doi: 10.1007/s10658-006-9039-y.

Boberg J, Björklund N. (2018) Synchytrium endobioticum - pathotypes, resistance of Solanum tuberosum and management. Report by Unit for Risk Assessment of Plant Pests at the Swedish University of Agricultural Sciences. 38 p. URL: https://www.slu.se/globalassets/ ew/org/centrb/riskv/pub/rapport-synchytriumendobioticum_21sept2018.pdf. (last accessed: 21.09. 2021).

Çakir E, Demirci F. (2017) A new pathotype of Synchytrium endobioticum in Turkey: Pathotype 2. Bitki koruma bulteni. 57(4):415-422. doi: 10.16955/bitkorb. 34044.1 .

EFSA. (2018) Pest categorisation of Synchytrium endobioticum. EFSA J. 16:5352. 36 pp. doi: 10.2903/j.efsa. 2018.5352.

EPPO phytosanitary procedures PM 3/59(3). (2017) Synchytrium endobioticum: descheduling of previously infested plots. (2017). Bulletin OEPP/EPPO Bulletin. 47(3):366-368. URL: https://onlinelibrary.wiley.com/ doi/epdf/10.1111/epp.12440 (last accessed: 21. 09.2021).

EPPO Standard PM 7/28(2) (2017) Synchytrium endobioticum. Bulletin OEPP/EPPO Bulletin 47(3):420-440. URL: https://onlinelibrary.wiley.com/doi/full/10.1111/epp. 12588. (last accessed: 21.09.2020).
EPPO GD. (2021) EPPO Global Database (available online). URL: https://gd.eppo.int. (last accessed: 21. 09.2021).

Fedotova TI. (1960) The potato wart viability determination. Zashhita rastenij ot vreditelej i boleznej. 8:11-12. (in Russian).

Fiers M, Chatot C, Edel-Hermann V, Le Hingrot Y. (2012) Potato soil-borne diseases. A review. Agronomy for Sustainable Development. 32(1):93-132. doi: 10.1007/ s13593-011-0035-z.

Ghoghoberidze S, Sikharulidze Z, Tsetskhladze Ts, Sikharulidze K, Zelya A. (2019) Distribution area and severity of potato wart Synchytrium endobioticum in Georgia. Tranzactions. Batumy. 5:57-63. http://science.org.ge/wpcontent/uploads/2021/04/ajara-works-V_compressedcompressed.pdf\#page $=57$.

Ghoghoberidze S, Sikharulidze Z, Tsetskhladze Ts, Sikharulidze K, Gorgiladze L, Papunidze V. (2020). Occurrence of the Pathotype 38 of Synchytrium endobioticum in Khulo Municipality of Georgia. Bull. Georgian Nat. Acad. Sci. 14(1):114-119. URL: http://science.org.ge/bnas/ t14-n1/17_Ghoghoberidze\%20et\%20al_Agrarian\%20 Sciences.pdf.

Glynne MD. (1926) The viability of the winter sporangium of Synchytrium endobioticum (Schilb.) Perc., the organism causing wart disease in potato. Ann. Appl. Biol. 13:1936. doi: /10.1111/j.1744-7348.1926.tb04250.x.

Golik IV. (1973) Technique for determining and fractionating potato wart zoosporangia causative agent. Trudy VIZR. 36:112-117 (in Russian).

Gorgiladze L, Meparishvili G, Sikharulidze Z, Natsarishvili K, Meparishvili S. (2014). First report of Synchytrium endobioticum causing potato wart in Georgia. New Disease Reports. 30(4). URL: http://www.ndrs.org.uk/ article.php?id $=030004$.

Hampson MC, Thompson PR. (1977) Quantitative method to examine large numbers of soil samples for Synchytrium endobioticum, the cause of potato wart disease. Plant Soil. 46:659-664.

Hampson MC, Robertson A. (1995) Distribution of fungal spores and fractal diversity of quadrats on membrane filters. J. Food Prot. 58:1038-1041.

Hampson MC, Coombes JW. (1996) Spatial distribution of Synchytrium endobioticum, the cause of potato wart, in field soil. Plant Dis. 80:1006-1010.

Jankauskas, B Jankauskiene G, Slepetiene A, Fullen MA, Booth CA. (2006) International comparison of analytical methods of determining the soil organic matter content of Lithuanian eutric albeluvisols. Commun. Soil Sci. Plant Anal. 37:707-720.

Laidlaw WMR. (1985) A method for the detection of resting sporangia of potato wart disease (Synchytrium endobioticum) in the soil of old outbreak sites. Potato Res. 28:223-232.

Marcus O. (1969) Untersuchungen zur Auszählung von Dauersporangien des Kartoffelkrebserregers Synchytrium 
endobioticum (Schilb.) Perc. in Bodenproben. Deutschen Planzenschutz. 21(10):153-157. URL: https://ojs. openagrar.de/index.php/NachrichtenblattDPD/issue/ view/1741. (last accessed: 25.08.2020).

Melnyk PO. (2003) Etiology of potato wart, the bioecological foundation for its prevention and development limitation. Chernivtsi: Prut, 284 p. (in Ukrainian).

Mygind H. (1961) Examination of soil samples for potato wart sporangia II. Acta Agriculturae Scandinavica, Section B. 11(1):114-120. doi: 10.1080/00015126109433047.

Nelson GA, Olsen OA. (1964) Methods for estimating number of resting sporangia of Synchytrium endobioticum in soil. Phytopatology. 54(2):185-186. https://www.cabdirect. org/cabdirect/abstract/19641102029. (last accessed: 21. 08.2020).

Niepold F, Stachewicz H. (2004) PCR-detection of Synchytrium endobioticum (Schilb.) Perc. J. Plant Dis. Prot. 111:313-321.

Obidiegwu JE, Flath K, Gebhardt C. (2014). Managing potato wart: a review of present research status and future perspective. Theor. App. Genet. Theoretische und angewandte Genetik. 127:763-780. https://doi.org/10. 1007/s00122-014-2268-0.

Omeluta VP, Ustynov ID, Filatova NK, Soloviova LM. (1996) Agricultural plant products. Methods of sampling in the process of quarantine inspection and examination: DSTU 3355 - 96 [Implemented since 07.01. 1997] Kyiv State Standard, 1996. 25 p.

Potoček J. (1977) Quantitative determination of resting zoosporangia of the potato wart pathogen in soil samples. Ochrana Rostlin. 13:251-256. (in Czech).

Pratt M. (1976) The Longevity of Resting Sporangia of Synchytrium endobioticum (Schilb.) Perc. in Soil. Bulletin OEPP/EPPO Bulletin. 6(2):107-108. doi: 10.1111/ j.1365-2338.1976.tb02026.x.

Przetakiewicz J. (2015a) The viability of winter sporangia of Synchytrium endobioticum (Schilb.) Perc. from Poland. Am. J. Potato Res. 92:704-708. doi: 10.1007/s12230015-9480-6.

Przetakiewicz J. (2015b) First report of new pathotype 39 (P1) of Synchytrium endobioticum causing potato wart disease in Poland. Plant Dis. 99(2):285. doi: 10.1094/ PDIS-06-14-0636-PDN.

Przetakiewicz J. (2017) Sampling, maintenance and pathotype identification of Synchytrium endobioticum (Schilb.) Perc. Plant Breed. Seed Sci. 76:29-36. doi: 10.1515/plass-2017-0018.

Putnam ML, Sindermann AB. (1994) Eradication of potato wart disease from Maryland. Am. Potato. J. 71:743-747.

Sharikov KE. (1954) Potato wart determination by microanalysis/Methodological recommendations. Minsk: 1954. 28 p. (in Russian).

Sikharulidze ZV, Ghoghoberidze SY, Mentink NM, Meparishvili GV, Tsetskhladze TsM, van Leeuwen GCM. (2019) Identification of the pathotype of Synchytrium endobioticum, causal agent of potato wart disease, present in Georgia. EPPO Bulletin. 49:314-320. https:// doi.org/10.1111/epp.12582.

Surnakova NE. (1992) Determination of native zoosporangia of Synchytrium endobioticum (Schilb.) Perc. Mikologija i fitopatologija. 16(4):313-314. (in Russian).

Tsvetkova YV, Yakovleva VA. (2021) Improvement of soil testing techniques for detecting spores of potato wart disease Synchytrium endobioticum using molecular methods. RUDN J. Agronom. Anim. Industr. 16(1):6676. (In Russian). doi: 10.22363/2312-797X-2021-16-166-76.

Van den Boogert PHJF, van Gent-Pelzer MPE, Bonants PJM, De Boer SH, Wander JGN, Levesque CA, van Leeuwen GCM, Baayen R. (2005) Development of PCR-based detection methods for the quarantine phytopathogen Synchytrium endobioticum, causal agent of potato wart disease. Eur. J. Plant Pathol. 113:47-57.

van Gent-Pelzer MPE, Krijger M, Bonants PJM. (2010) Improved real-time PCR assay for detection of the quarantine potato pathogen, Synchytrium endobioticum, in zonal centrifuge extracts from soil and in plants. Eur. J. Plant Pathol. 126(1):129-133.

van de Vossenberg B, Westenberg M, Adams I, Afanasenko $\mathrm{O}$, Beniusis A, Besheva A, Boerma M, Bonants $\mathrm{P}$, Choiseul J, Dekker T, Flath K, Heungens K, Karelov A, Przetakiewicz J, Schlenzig A, Yakovleva V, van Leeuwen G. (2018) EUPHRESCO Sendo: An international laboratory comparison study of molecular tests for Synchytrium endobioticum detection and identification. Eur. J. Plant Pathol. 151:757-766.

van Leeuwen GCM, Wander JGN, Lamers J, Meffert JP, van den Boogert PHJF, Baayen RP. (2005) Direct examination of soil for sporangia of Synchytrium endobioticum using chloroform, calcium chloride and zinc sulphate as extraction reagents. OEPP/EPPO Bull. 35:25-31.

Vladimirskaja NI. (1982) "Film" method for potato wart determination in sandy soil. Leningrad: 1982.36 p. (in Russian).

Wander JGN, van den Berg W, van den Boogert PHJF, Lamers JG, van Leeuwen GCM, Hendrickx G, Bonants P. (2007) A novel technique using the Hendrickx centrifuge for extracting winter sporangia of Synchytrium endobioticum from soil. Eur. J. Plant Pathol. 119:165174.

Zelya A H, Melnyk P O, Shevchenko N H et al. (2005) Express method for determining potato wart pathogen Synchytrium endobioticum (Schilb.) Perc. Karantyn i zakhyst roslyn. 10:13-15. (In Ukrainian).

Zelya AG, Melnyk PO, Matskiv TI, Movchan MO. (2006) Determination of potato wart pathogen Synchytrium endobioticum (Schilb.) Perc. in agrocenoses and cargos. Chernivtsi: Misto, 2006. 28 p. (In Ukrainian).

Zelya AH, Melnik PO, Makar TI et al. (2011) The 
investigation of potato cancer sites, Synchytrium endobioticum (Schilb). Perc. in Zakarpattia region. Karantyn i zakhyst roslyn. 11:26-27. URL: file:///C:/Users/User/ Downloads/Kizr_2011_6_12.pdf. (in Ukrainian).

Zelya AH, Matskiv TI, Hunchak VM et al. (2012) Agent of potato wart disease Synchytrium endobioticum (Schilb.) Perc. in Chernivetska region. Karantyn i zakhyst roslyn. 9:25-27. URL: http://kr.ipp.gov.ua/ index.php/journal/issue/view/74/9-2012-pdf. (in Ukrainian).

Zelya A, Gunchak V, Zelya G, Makar T, Kuvshynov O. (2017) The determination and identification of wart potato pathotypes Synchytrium endobioticum (Schlibersky) Percival in the Western Forest-Steppe of Ukraine. Interdepartmental Thematic Sci. Collec.Plant Protec. Quarant. 63:57-68. doi: 10.36495/1606-9773. 2017.63.57-68. (in Ukrainian).
Zelya A, Zelya G, Oliynyk T, Pylypenko L, Solomiychiuk M, Kordulean R, Skoreyko A, Bunduc Yu, Ghunchak V. (2018) Screening of potato varieties for multiple resistance to Synchytrium endobioticum in Western region of Ukraine. Agric. Sci. Pract. 3:3-11. doi.org/10. 15407/agrisp5.03.003.

Zelya AG, Gunchak VM, Melnik AT et al. (2020a) The phytosanitary state of potato wart Synchytrium endobioticum (Schlb.) Perc. sources in the Carpathian region of Ukraine. Karantyn i zakhyst roslyn. 4-6(261):9-15. doi: https://doi.org/10.36495/2312-0614.2020.4-6.9-15. (in Ukrainian).

Zelya AH, Oliynik TM, Zelya HV. (2020b) Selection of sources of potato resistance to wart Synchytrium endobioticum (Schilbersky) Percival. Peredhirne ta hirske zemlerobstvo i tvarynnytstvo. 67(2):75-91. doi: 1032636/01308521/2020-(67)-2-4. (Ukrainian). 